\title{
The Influence of Sr Addition on the Microstructure and Mechanical Properties of Aluminum Die-casting Alloys
}

\author{
Xiaodong SUN ${ }^{1, \mathrm{a}, *}$, Wenyun WU ${ }^{1, \mathrm{~b}}$, Donghong $\mathrm{WANG}^{1, \mathrm{c}}$ and Peiran DENG ${ }^{1, \mathrm{~d}}$ \\ ${ }^{1}$ School of Materials Engineering, Shanghai University of Engineering Science, Shanghai 201620, \\ China \\ a sunsiutung@163.com , ${ }^{\mathrm{b}}$ wenyjlu@126.com, ${ }^{\mathrm{c}}$ wdhcet6@163.com, peirandeng@126.com
}

\begin{abstract}
The effects of strontium addition on the microstructure and mechanical properties of aluminum alloys 380 and 413 are researched. All samples are prepared through high pressure die-casting, and the effect of the sample's thickness is also compared. The results indicate that the $\mathrm{Sr}$ addition can refine the metallographic microstructure of two alloys in different degrees, mainly to eutectic Si phase. The mechanical properties of the two alloys are improved slightly through Sr modification to the thin wall castings. The enhancement of mechanical properties is evident to the thick wall castings.
\end{abstract}

\section{Introduction}

The high pressure die-casting (HDPC) technic has been studied extensively since the commercialization of cast Al alloys. Owing to its high productivity and near-net shaping capability, high pressure die-casting is an economic processing technique that has been widely applied in various industrial fields, especially in the manufacture of automobile parts [1]. In various Al cast alloys, Al-Si alloys exhibit good castability and suitable for production of castings with high specific strength and relatively excellent corrosion resistance [2]. In a wide range of compositions, Al-Si series alloys with the eutectic or near eutectic composition account for most $\mathrm{Al}$ alloy castings.

Usually, the coarse and acicular Si phase in Al-Si alloy formed in solidification act as plausible sites for stress concentration when loading which will lead to premature crack [3]. The solidification speed in high pressure die-casting process is rapid comparatively, which results in thermal undercooling and promotes the formation of fine $\mathrm{Si}$ morphology. The casting parts with fine microstructure have high strength and toughness [4]. However, when the products are thick or uneven in thickness, the coarse acicular Si phase will form in the thick area which is weak in service. Various methods are adopted to modify the morphology of the Si phase [5-8]. Addition of slight elements is often considered to be an effective way. Of various elements, $\mathrm{Na}, \mathrm{P}$, and $\mathrm{Sr}$ have been commercially used [9-11]. With the overall performance, $\mathrm{Sr}$ exhibits a relatively good modification effect, and has therefore been extensively studied $[12,13]$. In this paper, the microstructure and mechanical properties of two commercial Al casting alloys 380 and 413 were compared with or without $\mathrm{Sr}$ addition. At same time, the effects of $\mathrm{Sr}$ modification in samples with different thickness

\footnotetext{
* Corresponding author: sunsiutung@163.com
} 
were also investigated.

\section{Experimental Procedure}

The experimental alloys were originally supplied in the form of industrial ingots which were cut, dried and melted in a preheated $\left(350 \pm 5^{\circ} \mathrm{C}\right)$ silicon carbide crucible of $60 \mathrm{~kg}$ capacity, using an electrical resistance furnace. The melting temperature was kept at $700 \pm 5^{\circ} \mathrm{C}$. After the alloy was completely melted, the Al- $10 \% \mathrm{Sr}$ master alloy was added into the melt at $700^{\circ} \mathrm{C}$ to obtain the alloy with $200-300 \mathrm{ppm}$ content of Sr. The melt was isothermally held at $720^{\circ} \mathrm{C}$ for about $30 \mathrm{~min}$ and stirred well to ensure complete homogenization.

The original and $\mathrm{Sr}$ modified alloys melt was manually dosed and subsequently released into the shot sleeve of a $6000 \mathrm{kN}$ HPDC machine for making standard tensile samples. The pouring temperature was $680^{\circ} \mathrm{C}$ measured by a K-type thermocouple. A specially designed die was used to cast six ASTM standard samples with three flat samples with different thickness for each shot. During casting, a water-based die releasing lubricant was used on the die block, which was pre-heated by the circulation of mineral oil at $250^{\circ} \mathrm{C}$ in all shots. All casting samples were left on floor for at least $24 \mathrm{~h}$ before testing their mechanical properties.

Metallographic specimens were all cut from the middle of the as-cast samples, then mechanically ground and polished in standard routines. The experimental samples were etched using Keller etchant ( $5 \mathrm{ml} \mathrm{HNO3,} 3 \mathrm{ml} \mathrm{HCl}, 2 \mathrm{ml} \mathrm{HF}$, and $190 \mathrm{ml}$ distilled water) for $5 \mathrm{~s}$. After etching in a Keller's reagent, the microstructure was observed using an optical microscope (OM, LEICA MEF4M).

\section{Results and Discussion}

\subsection{Microstructure}

Magnified micrographs were taken from etched specimens of original and $\mathrm{Sr}$ modified alloys for the analysis of the microstructure. The microstructures of as-cast 380 alloy and $\mathrm{Sr}$ modified samples at different thickness are shown in Fig. 1. As can be seen $\alpha$-Al dendrites, different morphology of Si particle can be found in both of unmodified and modified die cast 380 alloys. Compared the microstructures, block and acicular silicon can be found in the unmodified samples
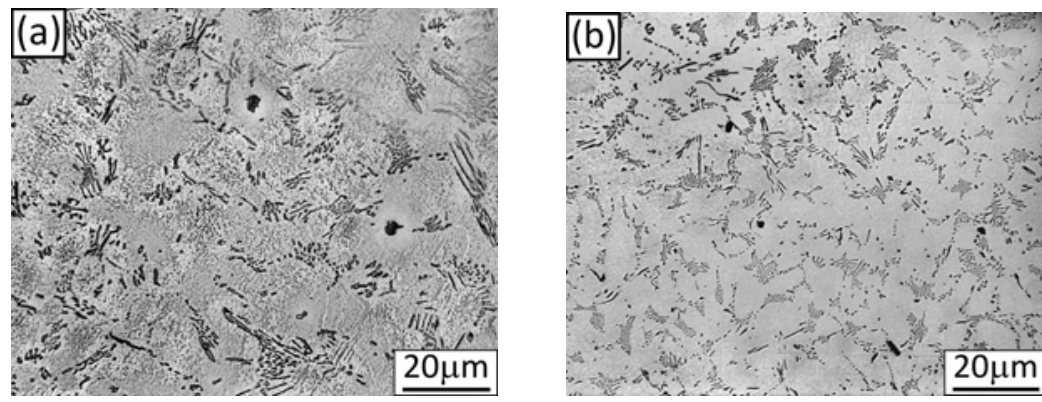

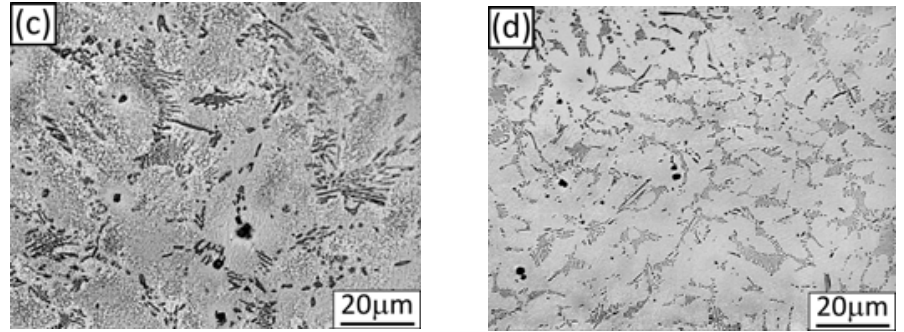

Fig. 1 Microstructure of 380 original and Sr modified alloys at $2 \mathrm{~mm}$ and $6 \mathrm{~mm}$ thickness

(a) No Sr 2mm, (b) Sr modified 2mm, (c) No Sr 6mm, (d) Sr modified 6mm

(Fig. 1 (a), (c)), after Sr addition, the morphology of eutectic silicon changing from coarse to fine (Fig. 1 (b), (d)). The eutectic cells can be found in modified alloy. The coupled growth of the $\alpha-\mathrm{Al}$ and Si eutectic in the Al-Si hypoeutectic system results in the formation of eutectic cells. At the same time a few intermetallic can be found both in the unmodified and modified microstructure due to the presence of $\mathrm{Cu}$ element. The acicular silicon phase is finer in the $2 \mathrm{~mm}$ thickness sample relative to that in $6 \mathrm{~mm}$ thickness sample owing to the higher cooling speed.

Fig. 2 shows the micrographs recorded from the 413 alloys with and without Sr contents. The changes in the microstructures of the eutectic Si are clearly evident. The microstructure of the unmodified alloy was characterized by coarse, acicular eutectic Si (see Fig. 2 (a) and (c)). Fig. 2 (b) and (d) shows the microstructures of the alloy with Sr addition. It is clear from the micrographs that the eutectic Si became finer as the morphology was changed to a mixture of conglobate and lamellar types, indicating the evident effect of the modifying element. The micrographs in Fig. 2 indicate that the morphology of the eutectic Si was greatly influenced by the $\mathrm{Sr}$ addition. This has been attributed to the effect of $\mathrm{Sr}$ addition on growth rate of eutectic Si particles. In the unmodified case, it is difficult to detect the eutectic cells, because of silicon flakes projecting ahead of the $\alpha$-Al phase in a nearly random group. In the case of alloys modified by $\mathrm{Sr}$, the solid-liquid growth front of the eutectic seems to be isothermal, and the eutectic cells formed [14]. Deference of microstructures between $2 \mathrm{~mm}$ thickness and $6 \mathrm{~mm}$ thickness samples is also obvious both in unmodified and modified alloy. The eutectic silicon phase is coarser in the $6 \mathrm{~mm}$ thickness sample.
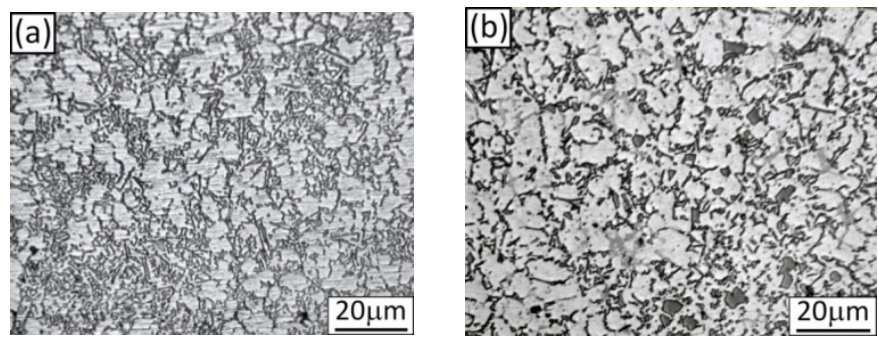

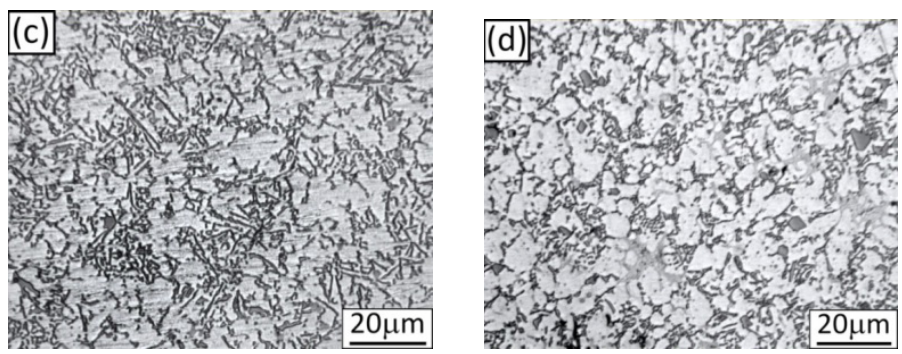

Fig. 2 Microstructure of 413 original and Sr modified alloys at $2 \mathrm{~mm}$ and $6 \mathrm{~mm}$ thickness

(a) No Sr 2mm, (b) Sr modified 2mm, (c) No Sr 6mm, (d) Sr modified 6mm

\subsection{Mechanical Properties}

The average of each experiment is presented in the Fig. 3 and Fig. 4. The bars shown represent the standard deviation of the experiment. The yield strength, ultimate tensile strength, and elongation values obtained from the original and modified 380 and 413 alloys were presented. The $X$-axis represents the thickness of test samples. The primary $Y$-axis represents the strength scale in MPa and the elongation in percentage.

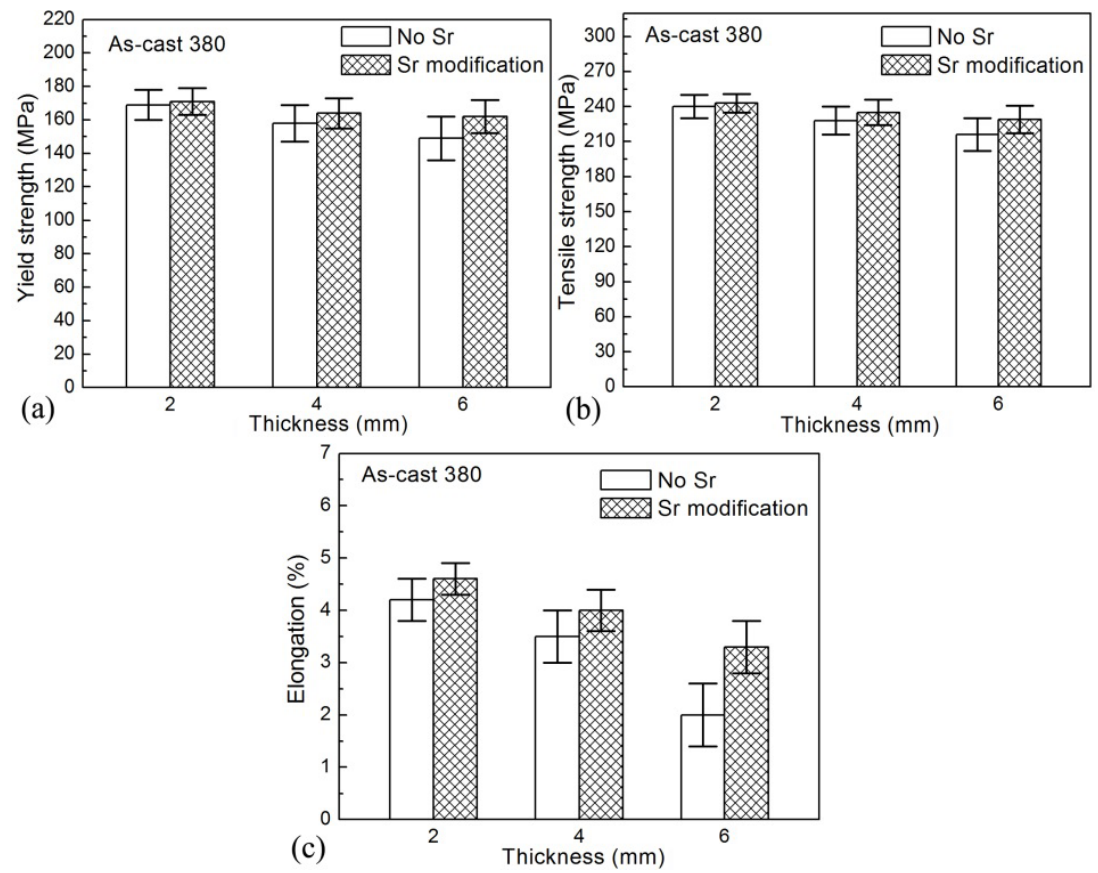

Fig. 3 Mechanical properties of original and Sr modified 380 alloys at different thickness

(a) Yield strength, (b) Tensile strength, (c) Elongation

The results show that the mechanical properties decline with the increase of samples' thickness. Sr-modification enhances the alloy mechanical properties, where Sr-modification shows marginally higher of yield and tensile strength compared to the unmodified alloy. This influence is evident to the thick samples (Fig 3 (a) (b), Fig 4 (a) (b)). The elongation to fracture was enhanced obviously to all thickness samples. And it is also more obvious to 
the thicker samples (Fig 3 (c), Fig. 4 (c)). The deviation of mechanical properties increases with the increment of samples' thickness due to the forming defects such as segregation, shrinkage porosity and so on. The gain in tensile ductility is largely attributed to the refinement of the eutectic Si phase in the Sr modified alloys. Upon loading, these acicular $\mathrm{Si}$ particles provide plausible sites for crack initiation and, therefore, degrade the mechanical properties of the alloy. The eutectic Si in modified alloys is modified to have a fine, spherical shape; consequently the mechanical properties of the alloys are improved. To thin samples, the eutectic Si phase can hardly grow up before solidification due to the high cooling speed despite no Sr addition. So the Sr modification treatment has little effect to the HPDC when the casting wall is thin. But to casting with thick wall the $\mathrm{Sr}$ modification is beneficial to the mechanical properties.

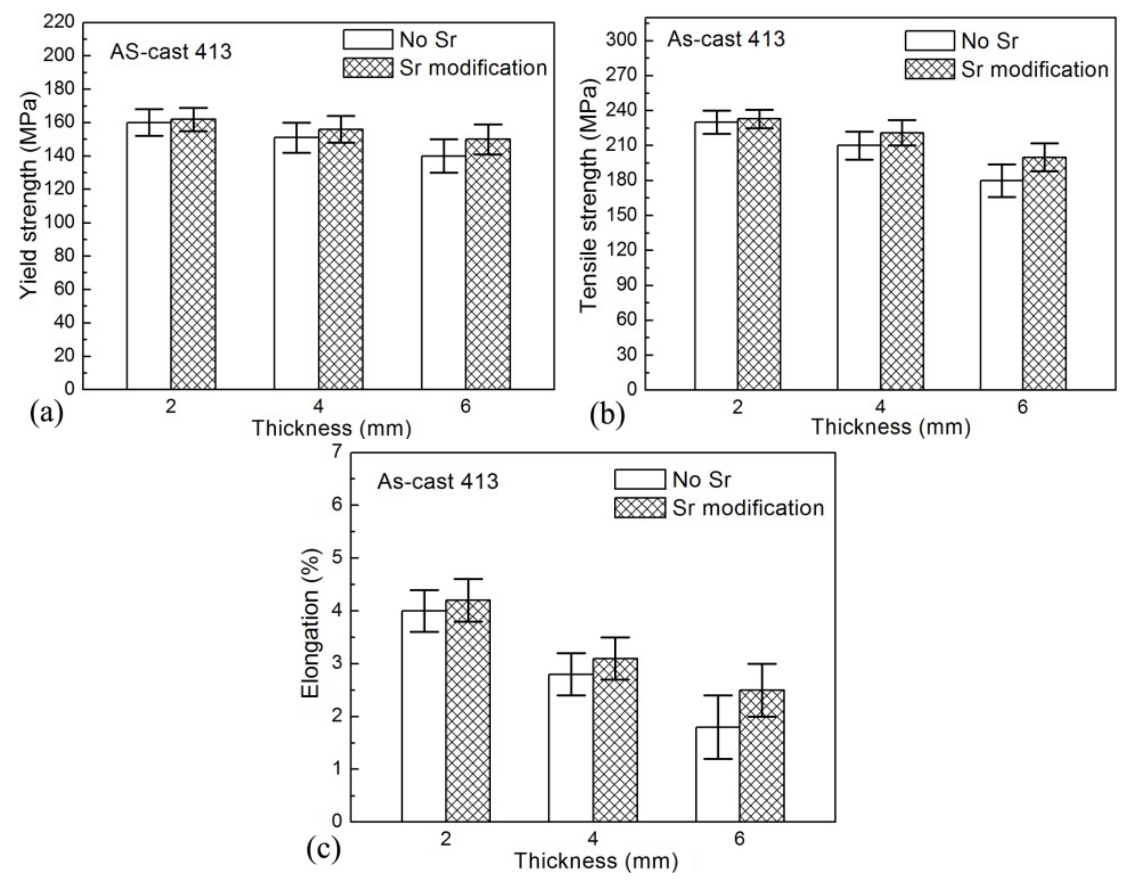

Fig. 4 Mechanical properties of original and Sr modified 413 alloys at different thickness

(a) Yield strength, (b) Tensile strength, (c) Elongation

\section{Conclusions}

The effect of $\mathrm{Sr}$ content on the microstructure and tensile properties of two commercial die-cast alloys 380 and 413 has been investigated. Based on the results obtained in the present study, the following conclusions can be drawn.

The morphology of eutectic Si phase in 380 and 413 alloys changed from acicular to fibrous. The effect is more obvious to castings with thick wall. The refinement of the eutectic Si phase by $\mathrm{Sr}$ modification can improve the mechanical properties slightly to castings with thin wall, but the improvement of mechanical propertied by $\mathrm{Sr}$ modification is obvious to thick wall castings. 


\section{Acknowledgements}

This research was supported by the Startup Project of Shanghai University of Engineering Science (No. 2014-32) and the Young Teachers Developing Plan of Shanghai Municipal Education Commission (No. ZZgcd14012) and the high level of cultivation project (2012gp23).

\section{References}

1. J ü rgen Hirsch, Recent development in aluminum for automotive applications, Transactions of Nonferrous Metals Society of China. 27, 7 (2014) 1995-2002.

2. H.C. Liao, M. Zhang, J.J. Bi, K. Ding, X. Xi, S.Q. Wu, Eutectic Solidification in Near-eutectic Al-Si Casting Alloys, Journal of Materials Science \& Technology. 26, 12 (2010) 1089-1097.

3. A. Gorny, J. Manickaraj, Z. Cai, S. Shanka, Evolution of Fe based intermetallic phases in Al-Si hypoeutectic casting alloys: Influence of the $\mathrm{Si}$ and $\mathrm{Fe}$ concentrations, and solidification rate, Journal of Alloys and Compounds. 577, 15 (2013) 103-124

4. R.N. Lumley, Progress on the heat treatment of high pressure die castings, Fundamentals of Aluminum Metallurgy. 2011, pp. 262-303

5. J. Sun, L. Zhang, G. Wu, W. Liu, Z. Hu, A. Chen, Refinement of primary Si in Al $20 \%$ Si alloy by MRB through phosphorus additions, Journal of Materials Processing Technology. 225 (2015) 485-491.

6. A.M. Samuel, G.H. Garza-Elizondo, H.W. Doty, F.H. Samuel, Role of modification and melt thermal treatment processes on the microstructure and tensile properties of Al-Si alloys, Materials \& Design. 80, 5 (2015) 99-108.

7. Sudha Joseph, S. Kumar, A systematic investigation of fracture mechanisms in Al-Si based eutectic alloy-Effect of Si modification, Materials Science and Engineering: A. 588, 20 (2013) 111-124.

8. Ogris E, Wahlen A, Luchinnger H, Uggowitzer PJ, On the silicon spheroidization in Al-Si alloys, Journal of Light Metals. 2 (2002) 263-9.

9. Garcia-Hinojosa JA, Gonzalez CR, Juárez JI, Surappa MK, Effect of Sr addition on an Al-7Si-10 vol.\% SiCp cast composites, Materials Science and Engineering A. 382 (2004) 315-20.

10. Espinoza-Cuadra J, Gallegos-Acevedo P, Mancha-Molinar H, Picado A, Effect of Sr and solidification conditions on characteristics of intermetallic in Al-Si 319 industrial alloys, Mater Des. 31 (2010) 343-56.

11. J. Eiken, M. Apel, S. Liang, Impact of $\mathrm{P}$ and $\mathrm{Sr}$ on solidification sequence and morphology of hypoeutectic Al.Si alloys: Combined thermodynamic computation and phase-field simulation, Acta Materialia. 98, 1 (2015) 152-163.

12. P. Srirangam, S. Chattopadhyay, A. Bhattacharya, S. Nag, J. Kaduk, Probing the local atomic structure of Sr-modified Al-Si alloys, Acta Materialia. 65, 15 (2014) 185-193

13. M. Timpel, N. Wanderka, G.S. Vinod Kumar, J. Banhart, Microstructural investigation of Sr-modified Al-15 $\mathrm{wt} \% \mathrm{Si}$ alloys in the range from micrometer to atomic scale, Ultramicroscopy. 111, 6, (2011) 695-700. 